\title{
Ruminal Temperature May Aid in the Detection of Subacute Ruminal Acidosis
}

\author{
O. AlZahal, ${ }^{*}$ E. Kebreab,† J. France, ${ }^{*}$ M. Froetschel,‡ and B. W. McBride*1 \\ *Centre for Nutritional Modeling, Department of Animal and Poultry Science, University of Guelph, Guelph, Ontario, Canada N1G 2W1 \\ †National Centre for Livestock and Environment, Department of Animal Science, University of Manitoba, Winnipeg, Manitoba, Canada R3T 2N2 \\ ¥Edgar L. Rhodes Center for ADS, University of Georgia, Athens 30602
}

\section{ABSTRACT}

The objective of this study was to investigate the relationship between ruminal $\mathrm{pH}$ and ruminal temperature and to develop a predictive equation that can aid in the diagnosis of subacute ruminal acidosis (SARA). Six rumen-fistulated lactating Holstein dairy cows (639 $\pm 51 \mathrm{~kg}$ body weight) were used in the study. Cows were randomly allocated to 1 of 2 dietary treatments: control (\% of dry matter, $40 \%$ corn silage, $27 \%$ mixed haylage, $7 \%$ alfalfa hay, $18 \%$ protein supplement, $4 \%$ ground corn, and $4 \%$ wheat bran) or SARA total mixed ration (\% of dry matter, $31 \%$ corn silage, $20 \%$ mixed haylage, $5 \%$ alfalfa hay, $15 \%$ protein supplement, $19 \%$ ground wheat, and $10 \%$ ground barley) and were fed daily at 0700 and $1300 \mathrm{~h}$. The experiment consisted of $1 \mathrm{wk}$ of adaptation followed by 1 wk of treatment. Ruminal $\mathrm{pH}$ and ruminal temperature were simultaneously and continuously recorded every minute for $4 \mathrm{~d}$ per week using the same indwelling electrode. Subacute-acidotic cows spent more time $(\mathrm{min} / \mathrm{d})$ below ruminal $\mathrm{pH} 5.6$ and a greater time above $39.2^{\circ} \mathrm{C}$ than control cows. Ruminal $\mathrm{pH}$ nadir had a negative relationship with its corresponding ruminal temperature $\left(\mathrm{R}^{2}=0.77\right)$. Therefore, ruminal temperature may have potential to predict ruminal $\mathrm{pH}$ and thus aid in the diagnosis of SARA. Key words: dairy cow, subacute ruminal acidosis, ruminal $\mathrm{pH}$, ruminal temperature

\section{INTRODUCTION}

Subacute ruminal acidosis (SARA) is a digestive disorder that affects health and productivity of high-yielding dairy cows. It is caused by feeding a diet rich in energy and low in structural carbohydrates that leads to accumulation of organic acids within the rumen (Kleen et al., 2003) and has been characterized as repeated bouts of depressed ruminal $\mathrm{pH}$ below 5.6 for 3

Received July 20, 2007.

Accepted September 27, 2007.

${ }^{1}$ Corresponding author: bmcbride@uoguelph.ca to $5 \mathrm{~h} / \mathrm{d}$ (AlZahal et al., 2007a). Herds with high incidence of SARA have been associated with high culling rate, increased death loss, and reduced milk production (Nocek, 1997). Clinical signs of SARA are difficult to detect and may include reduced DMI, diarrhea, rumenitis, and lameness or laminitis (Nordlund and Garrett, 1994). Common field techniques used to diagnose SARA include rumenocentesis and oral stomach tubing (Nocek, 1997; Enemark et al., 2004). Rumenocentesis has proven to be a more reliable technique for the determination of ruminal $\mathrm{pH}$ than oral stomach tubing because saliva contamination is often associated with the stomach tubing technique (Duffield et al., 2004; Enemark et al., 2004). Although rumenocentesis can be done with minimal disturbance, frequent sampling raises significant cow-comfort and ethical issues. Enemark et al. (2004) conducted a field study to evaluate the potential of various biochemical markers in blood, rumen, feces, and urine to predict ruminal $\mathrm{pH}$ and, thus, the presence of SARA. Their results revealed that only rumen propionate concentrations have the potential to predict ruminal $\mathrm{pH}$; however, this would still require collecting rumen fluid. The objectives of this study were to 1 ) induce SARA and simultaneously measure ruminal $\mathrm{pH}$ and ruminal temperature, 2) evaluate the potential of ruminal temperature to predict low ruminal $\mathrm{pH}$ and develop a predictive equation, and 3 ) evaluate the precision and accuracy of this equation.

\section{MATERIALS AND METHODS}

\section{Animals, Experimental Design, and Feeding}

Six rumen-fistulated multiparous lactating Holstein cows $(639 \pm 51 \mathrm{~kg}$ of BW, $140 \pm 59$ DIM, $39 \pm 11 \mathrm{~kg}$ of milk/d) were used in this study. The study consisted of 1 wk of dietary adaptation followed by 1 wk of treatment period. Cows were randomly assigned to 1 of 2 dietary treatments, control TMR or SARA TMR. Ingredients and chemical composition of experimental TMR are presented in Table 1 . The dietary treatments were fed twice a day at 0700 and $1300 \mathrm{~h}$. The amount of feed was offered to allow a maximum of $5 \mathrm{~kg}$ of orts. Feed 
Table 1. Ingredients and chemical composition of control and subacute ruminal acidosis (SARA) TMR

\begin{tabular}{|c|c|c|}
\hline Ingredient/diet & Control & SARA \\
\hline & & - \\
\hline Corn silage & 40.4 & 30.6 \\
\hline Mixed haylage & 26.9 & 20.4 \\
\hline Mixed hay & 6.9 & 5.2 \\
\hline Ground corn & 4.1 & 0.0 \\
\hline Wheat bran & 4.2 & 0.0 \\
\hline Ground wheat & 0.0 & 18.9 \\
\hline Ground barley & 0.0 & 9.5 \\
\hline Protein supplement $^{1}$ & 17.7 & 15.4 \\
\hline \multicolumn{3}{|l|}{ Chemical composition } \\
\hline $\mathrm{DM}, \%$ & 36.3 & 42.6 \\
\hline $\mathrm{CP}(\mathrm{N} \times 6.25)$ & 18.2 & 17.1 \\
\hline Soluble protein & 6.0 & 3.9 \\
\hline $\mathrm{ADF}$ & 27.0 & 21.0 \\
\hline $\mathrm{NDF}$ & 40.0 & 32.7 \\
\hline Lignin, \% NDF & 11.2 & 9.8 \\
\hline Crude fat & 2.4 & 2.0 \\
\hline Ash & 7.8 & 6.4 \\
\hline $\mathrm{NFC}^{2}$ & 31.6 & 41.8 \\
\hline Starch $^{3}$ & 12.6 & 24.1 \\
\hline $\mathrm{Ca}$ & 0.96 & 0.79 \\
\hline $\mathrm{P}$ & 0.50 & 0.45 \\
\hline $\mathrm{K}$ & 1.58 & 1.26 \\
\hline $\mathrm{Mg}$ & 0.33 & 0.29 \\
\hline $\mathrm{Na}$ & 0.32 & 0.29 \\
\hline $\mathrm{NE}_{\mathrm{L}},{ }^{4} \mathrm{Mcal} / \mathrm{kg}$ & 1.53 & 1.66 \\
\hline
\end{tabular}

${ }^{1}$ Contained (\% of DM): soybean meal, 24.8; high-protein corn gluten meal, 19.8; canola meal, 10.1; roasted soybean (whole), 10.4; fish meal (herring), 5.1; beet pulp, 1.3; calcium carbonate (limestone), 3.9; dicalcium phosphate, 4.9; soy hulls (ground), 5.9; sodium bicarbonate, 4.4; salt, 2.8; molasses (in pelleter), 1.8; urea, 2.8; magnesium oxide, 1.0; Organic Ruminant Micro Premix (Floradale Feed Mill Limited, Floradale, Ontario, Canada), 0.7; sulfur flour (99.5\%), 0.4; Rovimix Biotin (H-2, 20,000, DSM Nutritional Products Inc., Parsippany, NJ), 0.02 .

${ }^{2} \mathrm{NFC}=100-[\mathrm{NDF}+\mathrm{CP}+$ ether extract $+\mathrm{ash}]$.

${ }^{3}$ Analyzed according to Hall (2000).

${ }^{4}$ Calculated according to CPM-Dairy (v. 3.0.8, 2006) using the following animal descriptions: $\mathrm{BW}=650 \mathrm{~kg}$, milk $=38 \mathrm{~kg} / \mathrm{d}$, milk fat $=$ $3.8 \%$, milk $\mathrm{CP}=3.3 \%, \mathrm{DMI}=24.2 \mathrm{~kg} / \mathrm{d}, \mathrm{DIM}=120 \mathrm{~d}$.

intake was recorded daily during the treatment period. Diets were formulated to meet or exceed NRC (2001) guidelines for lactating dairy cows and water was offered at all times. Feed samples were collected twice a week. Equal subsamples, from collected feed samples throughout the experiment, were pooled and submitted for analysis at Agri-Food Laboratory, Guelph, Ontario, Canada, for DM, CP, Ca, P, Mg, K, Na, ash, ether extract, lignin, ADF (AOAC, 1996), NDF (Mertens, 2002), soluble CP (Licitra et al., 1996), and starch content (Hall, 2000).

The cows were housed in a tie-stall facility at the Elora Dairy Research Center, University of Guelph, Guelph, Ontario, and were cared for and handled in accordance with Canadian Council on Animal Care reg- ulations. The University of Guelph Animal Care Committee approved their use for this experiment.

\section{Ruminal $\mathrm{pH}$ and Ruminal Temperature Recording}

Ruminal $\mathrm{pH}$ and ruminal temperature were measured continuously and recorded every minute for $4 \mathrm{~d}$ during adaptation and treatment weeks using a mobile recording system described by AlZahal et al. (2007b). Two days of continuous ruminal $\mathrm{pH}$ recording, $1 \mathrm{~d}$ for cow no. 3168 and $1 \mathrm{~d}$ for cow no. 3178 on the SARA treatment during d 4, were missing. Briefly, each fistulated cow was equipped with a recording unit consisting of 2 major components: an indwelling $\mathrm{pH}$ electrode and a portable data logger. The electrode (PHE-7352-6PT100, Omega Engineering Inc., Stamford, CT) was heavy-duty and designed for submersible applications. The electrode had the ability to measure both $\mathrm{pH}$ and temperature simultaneously. The electrode was attached to a $0.5-\mathrm{kg}$ stainless steel weight that helped keep it within the ventral sac of the rumen. The electrode's cable was then connected to the data logger (pHTemp101, Monarch Instrument, Amherst, NH) for data acquisition. The data logger weighed $120 \mathrm{~g}$ and could hold up to 13,107 measurements per channel (pH and temperature). The source of power was a $9-\mathrm{V}$ lithium battery. The data logger was housed in a plastic waterproof box with an external input port to facilitate data downloading without opening the box. The box was then mounted on the animal's back using an adjustable belt fastened around the animal's girth. The data were collected from individual units using a personal digital assistant (Palm Inc., Sunnyvale, CA) equipped with Monarch PDA Software v 1.0 (Monarch Instrument). A desktop computer equipped with Data Recorder Software v 2.0 (Monarch Instrument) was used to calibrate electrodes, synchronize data from different loggers, display graphs, perform analyses (i.e., mean, standard deviation, minimum, and maximum), and transfer data to other programs. Calibration was performed every $4 \mathrm{~d}$ of recording using the desktop software. Standard buffer solutions of $\mathrm{pH} 4.00$ and 7.00 (Fisher Scientific, Fairlawn, NJ) were used for $\mathrm{pH}$ calibration. Temperature calibration was performed using room temperature $\left(22^{\circ} \mathrm{C}\right)$ as the low temperature calibration point, and factory calibration values were unchanged for the high temperature calibration point $\left(100^{\circ} \mathrm{C}\right)$. At the end of each calibration, electrodes were tested against a standard buffer and temperature.

\section{pH Curve Inflection Point}

The $\mathrm{pH}$ curve inflection point (IP) representing the effect of each dietary treatment on ruminal $\mathrm{pH}$ was 
Cut-off point $(\mathrm{pH}), x$

$\begin{array}{llllllllllllllll}5.0 & 5.2 & 5.4 & 5.6 & 5.8 & 6.0 & 6.2 & 6.4 & 6.6 & 6.8 & 7.0 & 7.2 & 7.4 & 7.6\end{array}$

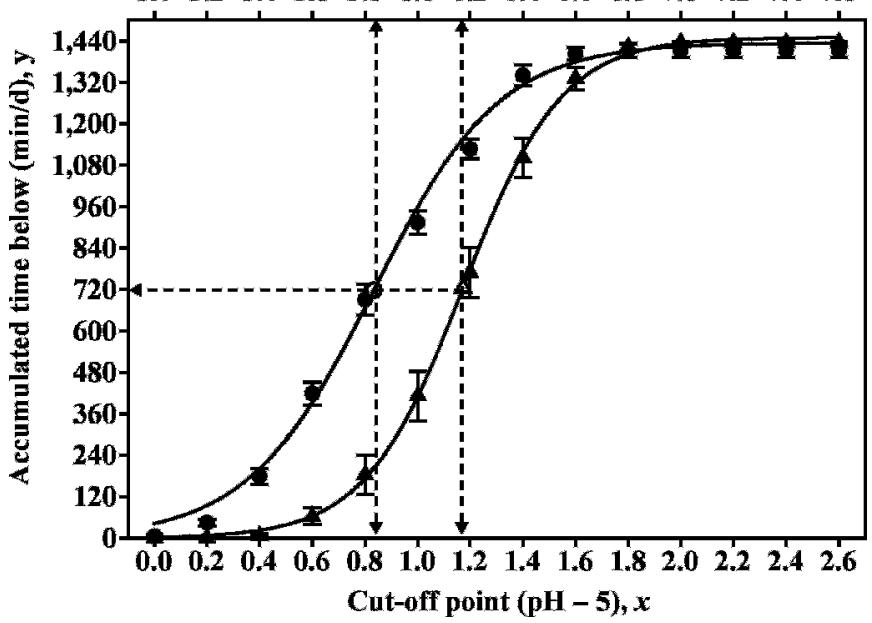

Figure 1. The pH curves for control and subacute ruminal acidosis (SARA) dietary treatments during wk 2 . The $y$-axis represents accumulated time (min/d) spent below each corresponding $\mathrm{pH}$ cut-off point on the $x$-axis. The values 0 to 2.6 on the primary $x$-axis (bottom) correspond with $\mathrm{pH} 5$ to 7.6 (top $x$-axis). Symbols and error bars represent the mean $\pm \mathrm{SE}$ of observed values for control $(\boldsymbol{\Delta}, \mathrm{n}=12)$ and $\operatorname{SARA}(\bullet, \mathrm{n}=10)$. Solid lines ( $\mathrm{pH}$ curves) were obtained by fitting the logistic function to $\mathrm{pH}$ data. The equations are: for control cows $y=2.7 \pm 1.0 \times 1,450.0 \pm 20.3 /[2.7 \pm 1.0+(1,450.0 \pm 20.3-2.7 \pm 1.0)$ $\exp (-5.4 \pm 0.3 x)], \mathrm{n}=12, \mathrm{R}^{2}>0.99, P<0.0001$; and for SARA cows $y=42.4 \pm 6.2 \times 1,434.2 \pm 16.7 /[42.4 \pm 6.2+(1,434.2 \pm 6.1-42.4 \pm$ $6.2) \exp (-4.2 \pm 0.16 x)], \mathrm{n}=10, \mathrm{R}^{2}>0.99, P<0.0001$. The $x$ - and $y$-coordinates of the point of inflection (IP) for control $(\Delta)$ and SARA (○) $\mathrm{pH}$ curves were indicated by arrows.

determined as described by AlZahal et al. (2007a). Briefly, daily $\mathrm{pH}$ records obtained during wk 2 were examined individually, and only records that contained $\geq 1,200$ data points per $\mathrm{d}$ were included in the analysis. Amounts of accumulated time ( $\mathrm{min} / \mathrm{d})$ spent below each $\mathrm{pH}$ cut-off point $(5.0,5.2, \ldots ., 7.6)$ were calculated for each cow in each day. A pH curve was constructed for each day of recording for each animal ( $y$-variate, 0 to $1,440 \mathrm{~min} / \mathrm{d} ; x$-variate, $\mathrm{pH} 5$ to 7.6 ; see for example Figure 1). In a previous study, AlZahal et al. (2007a), the logistic equation gave the best fit for $\mathrm{pH}$ curves. Therefore, in the current analysis, the logistic equation was fitted to $\mathrm{pH}$ curves from each dietary treatment separately using PROC NLMIXED of SAS:

$$
y(x)=\frac{y_{0} y_{f}}{\left[y_{0}+\left(y_{f}-y_{0}\right) \mathrm{e}^{-k x}\right]},
$$

where $y(x)=$ time spent below cut-off point $x(\mathrm{~min} / \mathrm{d})$; $x=\mathrm{pH}-5 ; y_{0}, y_{f}, k($ all $>0)$ are parameters that define the scale and shape of the curve.

The $\operatorname{IP}(x, y)$ of the logistic curves were determined for each dietary treatment as follows:

$$
\begin{gathered}
\operatorname{IP}(x)=\frac{1}{k} \ln \left(\frac{y_{f}-y_{0}}{y_{0}}\right) \\
\operatorname{IP}(y)=\frac{1}{2} y_{f}
\end{gathered}
$$

where $\operatorname{IP}(x)$ and $\operatorname{IP}(y)$ are the $x$ - and $y$-coordinates of the IP of the logistic curve.

Ruminal $\mathrm{pH}$ of a group of animals corresponding to a given dietary treatment can be described empirically by the position of the $\mathrm{pH}$ curve, which is indicated by $\mathrm{IP}(x)$ of that curve. A drop in ruminal $\mathrm{pH}$ means spending greater times below most critical $\mathrm{pH}$ cut-off points, which in turn translates into a shift of the $\mathrm{pH}$ curve position toward the lower $\mathrm{pH}$ ranges and a reduction in $\operatorname{IP}(x)$. Because studies in the literature that induced SARA nutritionally used different $\mathrm{pH}$ cut-off points to characterize ruminal $\mathrm{pH}$, the aforementioned approach provides a useful tool that utilizes all $\mathrm{pH}$ cut-off points and allows comparison across studies.

\section{Statistical Analysis}

Data analyses were conducted on measurements collected during treatment week (wk 2) of the experiment only. The nadir of $\mathrm{pH}$ and its corresponding temperature reading were determined for each day and cow during that period.

Daily average ruminal $\mathrm{pH}$ and temperature data (for example, mean, maximum, and time ( $\mathrm{min} / \mathrm{d}$ ) below or above a specific cut-off point) were analyzed using PROC MIXED of SAS (v 9.1; SAS Institute Inc., 2004) with day as a repeated measure. The model initially included the fixed effect of day, but this was not significant and was therefore removed. Analysis on weekly average DMI was conducted using PROC MIXED, and the model included the fixed effect of treatment.

Regression analysis of daily $\mathrm{pH}$ nadir against corresponding temperature was performed using PROC MIXED. The model included the fixed effects (slope and intercept) and the random effects (slope and intercept) for the independent variable (temperature). The fixed effects of the model were represented by the average of intercept and slope over all cows. The random effects of the model accounts for the random variation of intercept and slope from cow to cow. However, the random effect of slope was not significant and, thus, was removed from the model. The random effect of the intercept was left in the model whether it was significant or not to account for the experimental design. Also, the model included day as a repeated measurement with first-order auto regressive covariance structure. Adjusted observations (adjusted $y$ values) were calculated for graphing purposes, by addition of regression-predicted values to the residuals (St-Pierre, 2001). Ad- 
Table 2. Ruminal $\mathrm{pH}$ and ruminal temperature summary

\begin{tabular}{lcccr}
\hline Item & Control & SARA & SE & $P$-value \\
\hline $\mathrm{pH}$ & & & & \\
Mean & 6.17 & 5.84 & 0.05 & $<0.01$ \\
Maximum & 6.68 & 6.54 & 0.05 & 0.09 \\
Minimum & 5.51 & 5.09 & 0.06 & $<0.01$ \\
$<5.6 \mathrm{pH}^{1}$ & 60 & 412 & 38 & $<0.01$ \\
$<5.8 \mathrm{pH}^{2}$ & 174 & 687 & 74 & $<0.01$ \\
$<6.0 \mathrm{pH}^{3}$ & 405 & 907 & 91 & $<0.01$ \\
Temperature, ${ }^{\circ} \mathrm{C}$ & & & & \\
Mean & 38.54 & 39.21 & 0.22 & 0.05 \\
Maximum & 39.87 & 40.44 & 0.32 & 0.21 \\
Minimum & 36.70 & 36.75 & 0.23 & 0.89 \\
$>39.4^{\circ} \mathrm{C}^{4}$ & 139 & 561 & 156 & 0.07 \\
$>39.2^{\circ} \mathrm{C}^{5}$ & 263 & 723 & 149 & 0.04 \\
$>39.0^{\circ} \mathrm{C}^{6}$ & 418 & 884 & 158 & 0.05 \\
\hline
\end{tabular}

${ }^{1-3}$ Time $(\mathrm{min} / \mathrm{d})$ spent below $\mathrm{pH} 5.6,5.8$, and 6.0 , respectively.

${ }^{4-6}$ Time $(\mathrm{min} / \mathrm{d})$ spent above temperature $39.4,39.2$, and $39.0^{\circ} \mathrm{C}$, respectively.

justed $R^{2}$ was calculated using the GLM of SAS. The model included the adjusted observations as the dependent variables. Concordance correlation coefficient (Lin, 1989) was used to assess model precision and accuracy. The first component is the correlation coefficient (r) that measures precision. The second component $\left(\boldsymbol{C}_{\boldsymbol{b}}\right)$ is the bias correction factor that assesses model accuracy. If $C_{b}$ equals 1 , this indicates that no deviation from a line of unity has occurred. The product of both values gives both the precision and accuracy of the model simultaneously. Correlation was performed using PROC CORR of SAS.

\section{RESULTS AND DISCUSSION}

Dry matter intake of control $(21.6 \pm 1.3 \mathrm{~kg} / \mathrm{d})$ and SARA $(23.6 \pm 1.3 \mathrm{~kg} / \mathrm{d})$ treatments were not statistically different $(P=0.3)$. The nutritional practice successfully achieved a sustainable SARA during the treatment period (wk 2, Table 2). Ruminal $\mathrm{pH}$ data obtained during the adaptation period (wk 1) were not presented. Mean and minimum ruminal $\mathrm{pH}$ and time below $(\mathrm{min} / \mathrm{d}) \mathrm{pH}$ $5.6,5.8$, and 6.0 were significantly different between treatments. Control cows dropped below pH 5.6 for 60 $\mathrm{min} / \mathrm{d}$ compared with $412 \mathrm{~min} / \mathrm{d}(6.8 \mathrm{~h} / \mathrm{d})$ for SARA cows.

In a summary of our laboratory's previous SARA studies, AlZahal et al. (2007a) showed that diets containing $>40 \%$ dietary NFC (DM\%) reduced ruminal $\mathrm{pH}$ below 5.6 for $5.0 \mathrm{~h} / \mathrm{d}$ and had an $\operatorname{IP}(x)$ of 1.01. Also, diets containing 32 to $36 \%$ dietary NFC reduced ruminal $\mathrm{pH}$ below $\mathrm{pH} 5.6$ for $83 \mathrm{~min} / \mathrm{d}$ and had an $\operatorname{IP}(x)$ of 1.28. In the current study, the IP $(x)$ for SARA and control $\mathrm{pH}$ curves were 0.83 and 1.17 , respectively (Figure 1). Because $\operatorname{IP}(y)$ of a $\mathrm{pH}$ curve always occurs at the cut-off point $720 \mathrm{~min} / \mathrm{d}$ at the $y$ axis (Figure 1 ), the $\operatorname{IP}(x)$ can

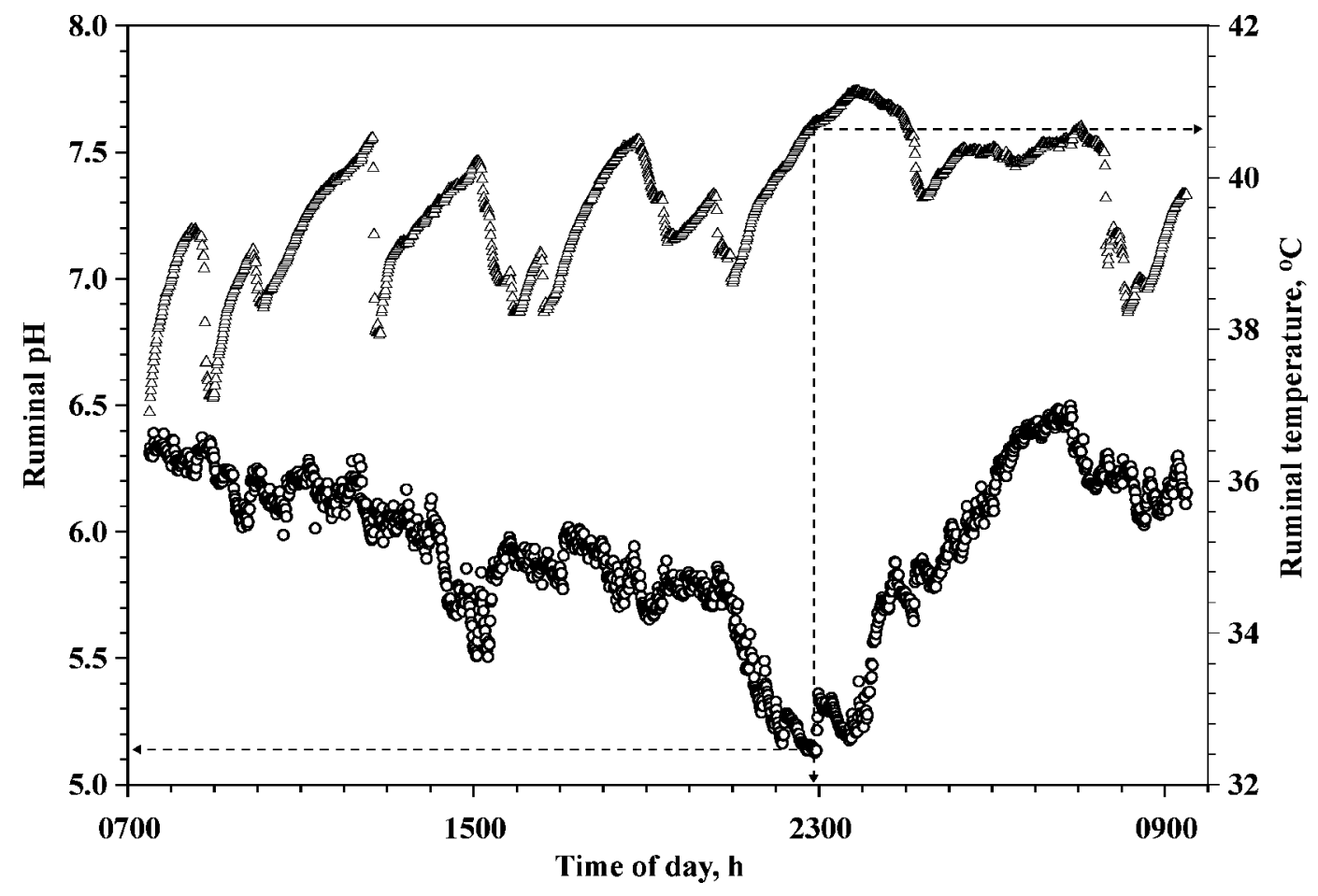

Figure 2. An example of 24-h ruminal $\mathrm{pH}(\bigcirc)$ and temperature $(\Delta)$ traces showing cow \#3178 during d 1 of experiment. The arrows indicate the nadir of $\mathrm{pH}$ on that day and its corresponding ruminal temperature reading. 


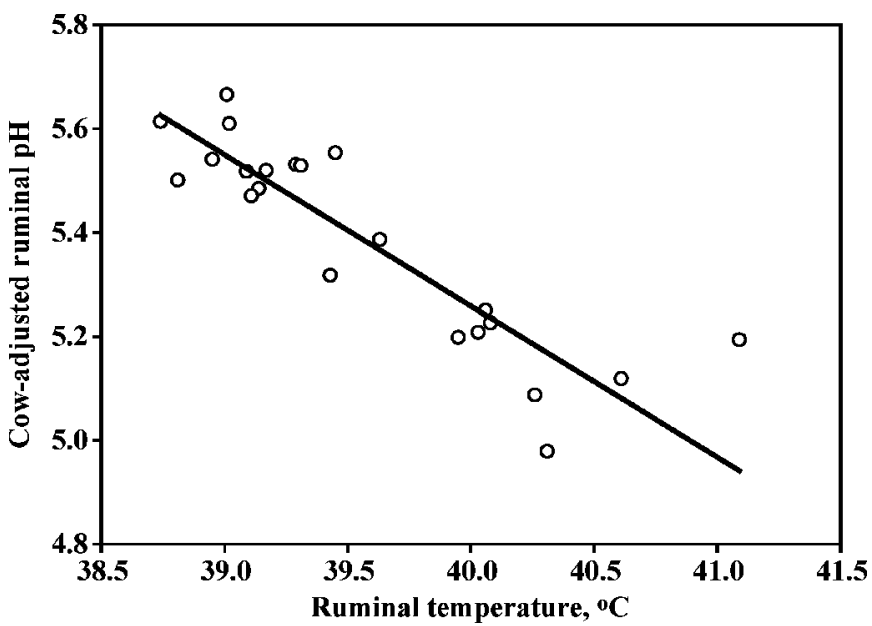

Figure 3. Relationship between ruminal temperature and cowadjusted ruminal $\mathrm{pH}$. Each data point represents nadir $\mathrm{pH}(x$-coordinate) and its corresponding ruminal temperature ( $y$-coordinate) obtained at the same time using the same electrode. Data points were extracted from ruminal $\mathrm{pH}$ and temperature continuously recorded over $4 \mathrm{~d}$ from 2 cows consuming the control diet and 2 cows consuming the subacute ruminal acidosis diet, 2 cow-day data points were missing. The solid line represents the regression equation: $\mathrm{pH}=(16.9 \pm$ $2.04)+(-0.29 \pm 0.052)$ Temperature, $\mathrm{R}^{2}=0.77, \mathrm{n}=22, P<0.002$.

be interpreted as a 720-min drop per day below $\mathrm{pH} 5.83$ and 6.17 for SARA and control, respectively (Figure 1).

The continuous ruminal $\mathrm{pH}$ system (AlZahal et al., $2007 \mathrm{~b}$ ) has the ability to monitor ruminal temperature and ruminal $\mathrm{pH}$, simultaneously using the same electrode. The results showed that ruminal temperature was inversely related to ruminal $\mathrm{pH}$ (Figure 2).

Ruminal temperature data were summarized similar to ruminal $\mathrm{pH}$ but using time spent over a given temperature threshold. Cows receiving the SARA diet had higher mean temperature and greater time $(\mathrm{min} / \mathrm{d})$ spent above 39.0 and $39.2^{\circ} \mathrm{C}$. Correlations between ruminal temperature and ruminal $\mathrm{pH}$ were highest for time above $39.4^{\circ} \mathrm{C}$ and time below $\mathrm{pH} 5.8,5.6$, and 6.0 ( $\mathrm{r}=0.46,0.45$, and 0.44 , respectively; $P<0.05$ ).

The relationship between ruminal $\mathrm{pH}$ nadir and ruminal temperature recorded at the same time has demonstrated a potential for ruminal temperature to predict ruminal $\mathrm{pH}$ minimum as follows (Figure 3):

$$
\begin{gathered}
\mathrm{pH}=(16.9 \pm 2.04)+(-0.29 \pm 0.052) \text { Temperature } \\
\mathrm{R}^{2}=0.77, \mathrm{n}=22, P=0.002 .
\end{gathered}
$$

Performance evaluation indicated that the model had high precision and accuracy $\left(\mathrm{r}=0.91, C_{b}=0.997\right.$, concordance correlation coefficient $=0.91$ ).

Ruminal temperature and ruminal $\mathrm{pH}$ were linearly associated within the range 39 to $41^{\circ} \mathrm{C}$, but the relationship would be expected to be nonlinear over extreme and extended ranges of temperature and $\mathrm{pH}$. The temperature range 39 to $41^{\circ} \mathrm{C}$ corresponds to the ruminal $\mathrm{pH}$ nadir range of 5 to 5.6 that is critical for detection of SARA. For example, inputting a temperature of $40^{\circ} \mathrm{C}$ into the equation gives a ruminal $\mathrm{pH}$ minimum of 5.3.

On the other hand, low ruminal temperature should not be translated as high ruminal $\mathrm{pH}$ due to possible interference of water and diet consumption (Figure 2). Time to nadir was not different between treatments and occurred $12.3 \pm 4.0 \mathrm{~h}$ after first feeding of the day $(0700 \mathrm{~h})$. This time corresponds to the least interference of drinking.

In the field, veterinarians diagnose SARA by collecting rumen fluid (rumenocentesis) at the time when ruminal $\mathrm{pH}$ is expected to be the lowest of the day. Nordlund and Garrett (1994) suggested that rumenocentesis should be performed 2 to $4 \mathrm{~h}$ after consuming the main grain meal of the day in component-fed herds and 4 to $8 \mathrm{~h}$ after feeding in TMR-fed herds. Because continuous ruminal temperature recording is not practical in a field situation, it is proposed a ruminal temperature reading be obtained at the time of nadir as suggested by Nordlund and Garrett (1994) as a noninvasive alternative to rumenocentesis. Drinking bouts should be avoided when ruminal temperature is taken.

The use of ruminal temperature to diagnose SARA in field situations depends on future development of a practical and cost-effective intraruminal wireless telemetry temperature sensing device (see for example Bewley et al., 2007). In conclusion, ruminal temperature can predict a ruminal $\mathrm{pH}$ minimum and has the potential to be developed into a noninvasive diagnostic technique to detect SARA in cattle.

\section{REFERENCES}

AlZahal, O., E. Kebreab, J. France, and B. W. McBride. 2007a. A mathematical approach to predict biological values from rumen pH measurements. J. Dairy Sci. 90:3777-3785.

AlZahal, O., B. Rustomo, N. E. Odongo, T. F. Duffield, and B. W. McBride. 2007b. A system for continuous recording of ruminal $\mathrm{pH}$ in cattle. J. Anim. Sci. 85:213-217.

AOAC. 1996. Official Methods of Analysis. 16th ed. Assoc. Off. Anal. Chem., Arlington, VA.

Bewley, J. M., M. W. Grott, D. C. Batson, and M. M. Schutz. 2007. Comparison of reticular and rectal core-body temperatures in lactating dairy cows. J. Dairy Sci. 90:3075. (Abstr.)

Duffield, T., J. C. Plaizier, A. Fairfield, R. Bagg, G. Vessie, P. Dick, J. Wilson, J. Aramini, and B. W. McBride. 2004. Comparison of techniques for measurement of rumen $\mathrm{pH}$ in lactating cows. J. Dairy Sci. 87:59-66.

Enemark, J. M. D., R. J. Jørgensen, and N. B. Kristensen. 2004. An evaluation of parameters for the detection of subclinical rumen acidosis in dairy herds. Vet. Res. Commun. 28:687-709.

Hall, M. B. 2000. Starch gelatinization and hydrolysis method. Pages 29-38 in Neutral Detergent Soluble Carbohydrates, Nutritional Relevance and Analysis - A Laboratory Manual. Dep. Anim. Sci., Univ. Florida, Gainesville.

Kleen, J. L., G. A. Hooijer, J. Rehage, and J. P. T. M. Noordhuizen. 2003. Subacute ruminal acidosis (SARA): A review. J. Vet. Med. Series A. Physiol. Pathol. Clin. Med. 50:406-414. 
Licitra, G., T. M. Hernandez, and P. J. Van Soest. 1996. Standardization of procedures for nitrogen fractionation of ruminant feeds. Anim. Feed Sci. Technol. 57:347-358.

Lin, L. I.-K. 1989. A concordance correlation coefficient to evaluate reproducibility. Biometrics 45:255-268.

Mertens, D. R. 2002. Gravimetric determination of amylase-treated neutral detergent fiber in feeds with refluxing in beakers or crucibles: Collaborative study. J. AOAC 85:1217-1240.

NRC. 2001. Nutrient Requirements of Dairy Cattle. 7th rev. ed. National Academies Press, Washington, DC.
Nocek, J. E. 1997. Bovine acidosis: Implications on laminitis. J. Dairy Sci. 80:1005-1028.

Nordlund, K. V., and E. F. Garrett. 1994. Rumenocentesis: A technique for collecting rumen fluid for the diagnosis of subacute rumen acidosis in dairy herds. The Bovine Practitioner 28:109-112.

SAS Institute Inc.. 2004. SAS/STAT Users Guide, release 9.1. SAS Inst. Inc., Cary, NC.

St-Pierre, N. R. 2001. Integrating quantitative findings from multiple studies using mixed model methodology. J. Dairy Sci. 84:741-755. 